\title{
Evaluation of the clinical and cardiorespiratory effects of propofol microemulsion in dogs
}

\author{
Efeitos clínicos e cardiorespiratórios do propofol em microemulsão em cães
}

\begin{abstract}
André Luís Corrêa ${ }^{\mathrm{I}}$ Renato Batista Tamanho"I Aury Nunes de Moraes ${ }^{\text {II }}$ Suzane Lilian Beier ${ }^{\text {III }}$ Doughlas Regalin" Felipe Hertzing Farias" ${ }^{\text {II }}$ Pâmela Spolti" ${ }^{\text {II }}$ Nilson Oleskovicz ${ }^{\text {II }}$
\end{abstract}

\section{ABSTRACT}

This research aimed to evaluate the clinical and cardiorespiratory effects of a propofol formulation with nanometer droplet diameter in dogs. Six adult healthy female dogs weighing $14.8 \pm 1.2 \mathrm{~kg}$ were used in this study. Each dog received two treatments with a 15-day washout period. A microemulsion (MICRO) or lipid emulsion (EMU) of propofol was administered intravenously (IV) for induction and maintenance of anesthesia. Anesthesia was maintained with a constant rate infusion of propofol $\left(0.4 \mathrm{mg} \mathrm{kg}^{-1}\right.$ minute $\left.{ }^{-1}\right)$. Cardiorespiratory variables were recorded before induction (baseline), immediately after and at 15-minute intervals for 90 minutes after treatment. Arterial blood samples were also taken for blood gas analysis, except at 45 and 75 minutes after induction. The mean arterial pressure decreased significantly during both treatments, while the cardiac index decreased significantly only in MICRO treatment. The time to extubation, sternal recumbency, ambulation and total recovery was similar in both treatments. Opisthotonos was observed in 33\% of the animals in each treatment. The propofol microemulsion presented clinical and respiratory parameters similar to those obtained with the lipid emulsion commercially available, but had some significantly different hemodynamic characteristics when used for inducing and maintaining anesthesia. Based only in these results, no advantages are seen in the use of this new microemulsion.

Key words: propofol, microemulsion, lipid emulsion, cardiorespiratory, dogs.

RESUMO

Este estudo tem o objetivo de avaliar os efeito clínicos e cardiorrespiratórios de uma formulação de propofol formada por nanopartículas, em cães. Para esse propósito, seis cães hígidos, adultos, fêmeas, com peso médio de 14,8土1,2kg foram utilizados. Cada cão recebeu dois tratamentos, sendo que entre estes foi permitido aos animais um periodo de washout de 15 dias. Os animais receberam propofol em microemulsão (MICRO) ou em emulsão lipídica (EMU) por via intravenosa (IV) para a indução e manutenção da anestesia. A anestesia foi mantida com velocidade de infusão constante $\left(0,4 m g \quad \mathrm{~kg}^{-1} \mathrm{~min}^{-1}\right)$. As variáveis cardiorrespiratórias foram mensuradas antes da indução (basal), imediatamente após a indução, e então a cada 15 minutos, durante 90 minutos. Amostras de sangue arterial também foram colhidas para análise de gases sanguíneos, exceto aos 45 e 75 minutos após a indução. A pressão arterial média diminuiu significativamente com a utilização de ambos os tratamentos, enquanto o índice cardiaco reduziu significativamente somente com o tratamento MICRO. O tempo necessário para extubação, decúbito esternal, deambulação e recuperação total foi semelhante em ambos os grupos. Opistótono foi observado em 33\% dos animais em cada tratamento. A microemulsão de propofol apresentou parâmetros clínicos e respiratórios semelhantes àqueles obtidos com a emulsão lipídica comercialmente disponivel, porém mostrou algumas características hemodinâmicas diferentes, quando utilizada para a indução e manutenção da anestesia. Com base somente nesses resultados, não são observadas vantagens na utilização da microemulsão.

Palavras-chave: propofol, microemulsão, emulsão lipídica, cardiorrespiratória, cães.

\section{INTRODUCTION}

When new formulations of a drug are developed, studies are required to check for possible alterations in its pharmacokinetic and

IDepartamento de Cirurgia, Faculdade de Medicina, Universidade de São Paulo (USP), Avenida Doutor Arnaldo, 455, Cerqueira César, 01246-000, São Paulo, SP, Brasil. E-mail: andrecorrea@usp.br. Autor para correspondência.

IDepartamento de Medicina Veterinária, Centro de Ciência Agroveterinárias, Universidade do Estado de Santa Catarina (UDESC), Lages, SC, Brasil.

IIIDepartamento de Clínica e Cirurgia Veterinárias, Escola de Veterinária, Universidade Federal de Minas Gerais (UFMG), Belo Horizonte, MG, Brasil. 
pharmacodynamic properties. Some studies have observed differences related to the effects of new propofol formulations (FECHNER et al., 2004; DUBEY \& KUMAR, 2005), such as pain on injection, and hemodynamic and respiratory effects. Formulations in microemulsion have also been proposed to minimize some undesired characteristics from the propofol in lipid emulsion, such as the relatively short storage time, the requirement of controlled temperature and the support for bacterial growth (MOREY et al., 2006).

Differently from the propofol in lipid emulsion, the pharmaceutical composition used in this study is an injectable oil-water microemulsion of propofol, with reduced dispersed hydrophobic particles $(1-50 \mathrm{~nm})$, transparent and with a viscosity comparable to that of an aqueous solution. So, the purpose of this study was to test the hypothesis that this new propofol formulation would have different clinical and cardiorespiratory characteristics compared to the lipid emulsion formulation.

\section{MATERIAL AND METHODS}

Six healthy female mongrel dogs, aged 1-4 years, were enrolled in the study. The mean \pm SD weight of the dogs was $14.8 \pm 1.2 \mathrm{~kg}$. Health status was assessed on the basis of results of a physical examination, complete blood count, and serum biochemical analyses. Dogs were housed in individual cages, fed with dry dog food, and provided with water ad libitum.

Food and water were withheld for 12 and 2 hours, respectively, prior to the instrumentation period. General anesthesia was induced by the inhalation of isoflurane $^{\mathrm{a}}(5 \mathrm{v} \%)$ in $5 \mathrm{~L}$ minute $^{-1}$ oxygen using a mask connected to a circle breathing circuit.

Venous catheters ${ }^{\text {b }}$ (20-gauge) were placed in both cephalic veins, one for the infusion of lactated ringer solution $\left(5 \mathrm{~mL} \mathrm{~kg}^{-1}\right.$ hour-1) and another for propofol administration. In order to monitor the arterial blood pressure, a 20-gauge catheter was placed in the femoral artery and connected to a disposable transducer and a multiparametric monitor ${ }^{\mathrm{c}}$. The cardiac output (CO) was obtained using the thermodilution technique. For this, a six French catheter introducer ${ }^{\mathrm{d}}$ was placed into the jugular vein and a pulmonary artery catheter ${ }^{\mathrm{e}}$ ( 5 French, 4 lumen) was then advanced via the introducer, until its distal lumen was positioned in the main pulmonary artery. Its correct location was confirmed on the observation of characteristic pressure waveforms. The proximal lumen recorded the central venous pressure (CVP), while its distal lumen recorded the mean pulmonary arterial pressure (mPAP) and the pulmonary artery occlusion pressure (PAOP). PAOP was obtained by inflating temporarily the balloon located at the tip of the pulmonary artery catheter.

In order to perform the $\mathrm{CO}$ measurements, $5 \mathrm{~mL}$ boluses of cold saline solution $(0.9 \% \mathrm{NaCl})$ were administered into the central venous port of the pulmonary artery catheter. This solution was always administered by the same person at the end of expiration. The $\mathrm{CO}$ was measured three times, and the arithmetic mean of the three values was used for each time point. Measures with a difference higher than $10 \%$ from the previous one were excluded.

At the end of the instrumentation period, all the catheters were filled with $0.9 \% \mathrm{NaCl}$ solution containing heparin $\left(5 \mathrm{IU} \mathrm{mL} \mathrm{mL}^{-1}\right)$ and occluded until the start of baseline data collection. A 60 minute-period was given to allow complete recovery from inhalant anesthesia.

\section{Experimental design}

All the animals were submitted to a randomized, crossover design, receiving both formulations of propofol ${ }^{\mathrm{f}, \mathrm{g}} \mathrm{IV}$ to induce and maintain anesthesia. Each animal was its own control and a 15day period was allowed between each treatment.

Baseline cardiorespiratory variables were measured 10 minutes before the propofol induction (T-10) and included: heart rate (HR; beats minute $^{-1}$ ), systolic (SAP), diastolic (DAP) and mean arterial pressure (MAP; $\mathrm{mmHg}$ ), CVP $\left(\mathrm{cmH}_{2} \mathrm{O}\right), \mathrm{CO}\left(\mathrm{L} \mathrm{minute}^{-1}\right), \mathrm{mPAP}(\mathrm{mmHg})$ and PAOP $(\mathrm{mmHg})$, respiratory rate $\left(\mathrm{f}_{\mathrm{R}}\right.$; breaths minute $\left.{ }^{-1}\right)$, body temperature $\left(\mathrm{BT} ;{ }^{\circ} \mathrm{C}\right.$ ) and arterial blood gas (partial pressure of oxygen - $\mathrm{paO}_{2}$ and carbon dioxide $\mathrm{paCO}_{2}(\mathrm{mmHg}), \mathrm{pH}, \mathrm{HCO}_{3}^{-}\left(\mathrm{mEq} \mathrm{L}^{-1}\right)$, base excess $\mathrm{BE}\left(\mathrm{mEq} \mathrm{L}^{-1}\right)$, and oxyhemoglobin saturation - $\mathrm{SaO}_{2}$ $(\%)$ ). Variables obtained by calculation included: cardiac index (CI; L minute ${ }^{-1} \mathrm{~m}^{-2}$ ) and stroke volume index (SVI; mL beat ${ }^{-1} \mathrm{~kg}^{-1}$ ), the pulmonary (PVRI; dynes seconds $\mathrm{cm}^{-5} \mathrm{~m}^{-2}$ ) and systemic (SVRI; dynes seconds $\mathrm{cm}^{-5} \mathrm{~m}^{-2}$ ) vascular resistance indices, and the left (LVSWI; cJ) and right (RVSWI; cJ) ventricular stroke work indices.

Anesthesia was induced with propofol administered by slow IV injection to effect, and the end point was considered to achieve lateral recumbency and reduction in jaw tone sufficient to allow orotracheal intubation. Anesthesia was maintained using a syringe pump ${ }^{\mathrm{h}}$ at a constant rate infusion (CRI) of $0.4 \mathrm{mg} \mathrm{kg}^{-1}$ minute $^{-1}$, and the animals were allowed to breathe spontaneously. After induction 
of anesthesia, data were collected approximately 1 minute after intubation, and also at $15,30,45,60$, 75 and 90 minutes (T0, T15, T30, T45, T60, T75 and T90). Arterial blood samples $(0.3 \mathrm{~mL})$ were obtained from the femoral artery using heparinized insulin syringes and analyzed for blood gas analysis at the same time points, except at T45 and T75.

The occurrence of adverse effects, the presence of excitement or pain during propofol injection, as well as the intubation quality were evaluated. During the recovery period, possible adverse effects, time (minutes) for extubation (EXT), sternal recumbency (STR), ambulation (AMB) and total recovery (TREC) were also recorded.

One-way analysis of variance (ANOVA) with repeated measures was used to evaluate withingroup changes in parametric variables over time, followed by Dunnet post hoc analysis. The paired $t$-test was used for paired data to detect differences between the groups $(\mathrm{P}<0,05)$.

\section{RESULTS AND DISCUSSION}

The induction dose did not differ significantly between treatments $(8.3 \pm 1.0 \mathrm{mg}$ $\mathrm{kg}^{-1}$ and $7.9 \pm 0.4 \mathrm{mg} \mathrm{kg} \mathrm{kg}^{-1}$ for the MICRO and EMU treatment, respectively). All the animals had a smooth and rapid induction, with no signs of excitement, pain on injection or any other undesired effect. Intubation was easily performed in all animals. The constant rate infusion $(0.4 \mathrm{mg}$ $\mathrm{kg}^{-1} \mathrm{~min}^{-1}$ ) was selected based on a previous study performed by OLESKOVICZ (2009).

As obtained by FERRO et al. (2005) with the use of a conventional propofol CRI of $0.4 \mathrm{mg} \mathrm{kg}^{-1}$ minute $^{-1}$ in dogs, the HR in our study did not present significant alterations throughout the experiment period when both formulations were used (Table 1). Increases heart rate in response to a reduction in the arterial blood pressure are usually not observed when propofol is being used, this may be due to the fact

Table 1 - Mean values and standard deviation of heart rate (HR; beats minute $\left.{ }^{-1}\right)$, mean and pulmonary arterial pressure (MAP, mPAP), systemic vascular resistance index (SVRI; dynes seconds $\mathrm{cm}^{-5} \mathrm{~m}^{-2}$ ), left and right ventricular stroke work index (LVSWI; cJ; RVSWI; cJ), pulmonary vascular resistance index (PVRI; dynes seconds $\mathrm{cm}^{-5} \mathrm{~m}^{-2}$ ), $\mathrm{pH}$, arterial partial pressure of carbon dioxide $\left(\mathrm{PaCO}_{2} ; \mathrm{mmHg}\right)$ in female dogs submitted to anesthetic induction and maintenance using propofol in microemulsion $(\mathrm{M}$; $\mathrm{n}=6)$ or lipid emulsion $(\mathrm{E} ; \mathrm{n}=6)$.

\begin{tabular}{|c|c|c|c|c|c|c|c|c|c|}
\hline & G & $\mathrm{T}-10$ & T0 & $\mathrm{T} 15$ & T30 & $\mathrm{T} 45$ & T60 & T75 & T90 \\
\hline \multirow{2}{*}{ HR } & $\mathrm{M}$ & $118 \pm 18$ & $123 \pm 25$ & $123 \pm 23$ & $119 \pm 20$ & $120 \pm 16$ & $121 \pm 13$ & $121 \pm 18$ & $129 \pm 17 \mathrm{a}$ \\
\hline & $\mathrm{E}$ & $120 \pm 19$ & $126 \pm 6$ & $114 \pm 13$ & $108 \pm 15$ & $111 \pm 23$ & $108 \pm 25$ & $105 \pm 1$ & $108 \pm 20 b$ \\
\hline \multirow{2}{*}{ MAP } & M & $102 \pm 8$ & $85 \pm 9^{*}$ & $72 \pm 12 *$ & $71 \pm 11 *$ & $75 \pm 13 *$ & $83 \pm 13^{*}$ & $89 \pm 13^{*}$ & $93 \pm 15$ \\
\hline & $\mathrm{E}$ & $97 \pm 12$ & $82 \pm 7 *$ & $67 \pm 7 *$ & $74 \pm 12 *$ & $78 \pm 12 *$ & $83 \pm 11 *$ & $88 \pm 13$ & $92 \pm 14$ \\
\hline \multirow{2}{*}{ SVRI } & M & $2645 \pm 625$ & $2569 \pm 491$ & $2434 \pm 672$ & $2277 \pm 479$ & $2501 \pm 531$ & $2689 \pm 369$ & $2877 \pm 531$ & $2899 \pm 611$ \\
\hline & $\mathrm{E}$ & $2419 \pm 527$ & $2166 \pm 554$ & $1859 \pm 550^{*}$ & $2274 \pm 542$ & $2230 \pm 403$ & $2588 \pm 482$ & $2533 \pm 561$ & $2806 \pm 856$ \\
\hline \multirow{2}{*}{ LVSWI } & M & $1.58 \pm 0.4$ & $1.04 \pm 0.23 *$ & $0.80 \pm 0.2^{*}$ & $0.82 \pm 0.13 *$ & $0.8 \pm 0.27 * \mathrm{a}$ & $0.94 \pm 0.18^{*}$ & $1.00 \pm 0.16^{*} \mathrm{a}$ & $1.03 \pm 0.16^{*} \mathrm{a}$ \\
\hline & $\mathrm{E}$ & $1.44 \pm 0.44$ & $1.19 \pm 0.38$ & $1.02 \pm 0.35^{*}$ & $1.03 \pm 0.25^{*}$ & $1.16 \pm 0.31 b$ & $1.16 \pm 0.22$ & $1.36 \mathrm{~b} \pm 0.37$ & $1.36 \mathrm{~b} \pm 0.37$ \\
\hline \multirow{2}{*}{ mPAP } & M & $13 \pm 3$ & $13 \pm 2 \mathrm{a}$ & $10 \pm 3 * a$ & $10 \pm 3 * a$ & $10 \pm 3 *$ & $11 \pm 3 * \mathrm{a}$ & $11 \pm 4$ & $12 \pm 3 \mathrm{a}$ \\
\hline & $\mathrm{E}$ & $12 \pm 4$ & $10 \pm 2 * b$ & $7 \pm 2 * b$ & $7 \pm 2 * b$ & $9 \pm 2 *$ & $8 \pm 3 * b$ & $8 \pm 3 *$ & $9 \pm 3 * b$ \\
\hline \multirow{2}{*}{ PVRI } & M & $254 \pm 81$ & $264 \pm 80$ & $257 \pm 69 a$ & $256 \pm 46$ & $248 \pm 92$ & $243 \pm 57 \mathrm{a}$ & $236 \pm 49$ & $233 \pm 42$ \\
\hline & $\mathrm{E}$ & $232 \pm 92$ & $208 \pm 93$ & $162 \pm 92 b$ & $171 \pm 87$ & $187 \pm 91$ & $183 \pm 72 b$ & $177 \pm 76$ & $184 \pm 82$ \\
\hline \multirow{2}{*}{ RVSWI } & M & $0.21 \pm 0.07$ & $0.15 \pm 0.04 *$ & $0.11 \pm 0.03 *$ & $0.12 \pm 0.03^{*}$ & $0.11 \pm 0.03 *$ & $0.12 \pm 0.04 *$ & $0.12 \pm 0.04 *$ & $0.13 \pm 0.02 *$ \\
\hline & $\mathrm{E}$ & $0.18 \pm 0.07$ & $0.14 \pm 0.04 *$ & $0.10 \pm 0.03 *$ & $0.10 \pm 0.03^{*}$ & $0.12 \pm 0.03^{*}$ & $0.11 \pm 0.04 *$ & $0.13 \pm 0.04 *$ & $0.12 \pm 0.05 *$ \\
\hline \multirow{2}{*}{$\mathrm{pH}$} & M & $7.40 \pm 0.04$ & $7.29 \pm 0.04 *$ & $7.34 \pm 0.03 *$ & $7.33 \pm 0.03 *$ & - & $7.34 \pm 0.03 *$ & - & $7.35 \pm 0.03 *$ \\
\hline & $\mathrm{E}$ & $7.42 \pm 0.02$ & $7.32 \pm 0.04 *$ & $7.30 \pm 0.04 *$ & $7.32 \pm 0.02 *$ & - & $7.35 \pm 0.03 *$ & - & $7.35 \pm 0.02 *$ \\
\hline \multirow{2}{*}{$\mathrm{PaCO}_{2}$} & M & $26.6 \pm 3.2$ & $40.8 \pm 5.7 *$ & $37.5 \pm 5.0^{*}$ & $39.5 \pm 3.6^{*}$ & - & $38.0 \pm 4.4^{*}$ & - & $36.9 \pm 4.9^{*}$ \\
\hline & $\mathrm{E}$ & $27.0 \pm 3.4$ & $39.1 \pm 5.1^{*}$ & $41.4 \pm 9.0^{*}$ & $40.4 \pm 5.0^{*}$ & - & $37.0 \pm 4.7^{*}$ & - & $36.6 \pm 3.8^{*}$ \\
\hline
\end{tabular}

*statistically significant difference from $\mathrm{T}-10$, Dunnet's test $(\mathrm{P}<0,05)$. a,b in the columns, indicate a different value between the groups, paired $t$ test $(\mathrm{P}<0,05)$.

Ciência Rural, v.43, n.6, jun, 2013. 
that propofol can decrease the baroreflex sensitivity (BRANSON, 2007).

No significant differences were observed in SAP, DAP and MAP values between treatments, but a similar significant reduction of these parameters occurred in both groups (Figure 1). This reduction is probably related to both the reduction of the SVRI and the CI, as seen below. A decrease in blood pressure in dogs receiving propofol was also seen by FERRO et al. (2005). Although our mean pressure values are above the ones considered sufficient to maintain perfusion to all vital organs and tissues (MAP $>65 \mathrm{mmHg}$; Table 1 ), this reduction could be important in populations affected by systemic disease.

In animals receiving MICRO, a decrease of $22 \%$ in the CI was observed in comparison to baseline values, and the SVI was significantly lower during all the infusion period, presenting a $25 \%$ decrease, with mean values significantly lower with the use of the MICRO, at T15 and from T45 to T90.
According to NAKAIGAWA et al. (1995), the CI decrease is related to the change in SVI during propofol anesthesia and it is believed that the same situation happened on our study (Figure 1). Changes in SVI depend on several factors, such as changes in preload and in myocardial contractility. HETTRICK et al. (1997) observed a reduction in stroke volume in dogs receiving a propofol CRI of $0.3 \mathrm{mg} \mathrm{kg}^{-1} \mathrm{~min}^{-1}$. It was found that this reduction on stroke volume was due to a reduction in myocardial contractility. Some authors use the LVSWI as an indicator of cardiac contractility, but based on the research data, it cannot be affirmed that there was a direct myocardial depression in our study. A reduction of the LVSWI values was seen at $\mathrm{T} 15$ and at $\mathrm{T} 30$ in animals receiving EMU, and during all the infusion period with the use of MICRO, and this effect was more evident in this latter (Table 1).

A decrease in CVP was observed in both groups, but this reduction was significant only in animals in EMU group (Figure 1). The reduced

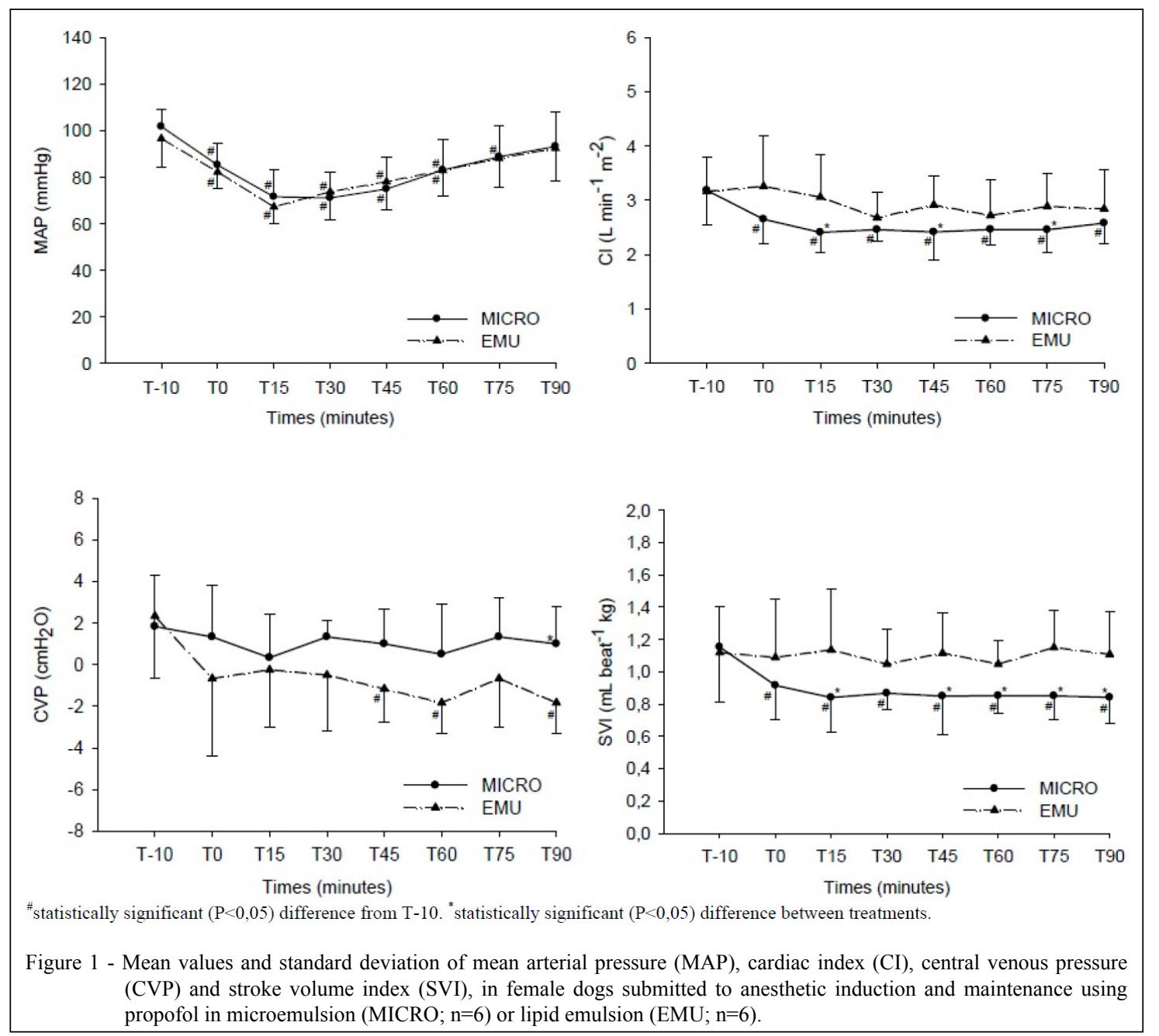

Ciência Rural, v.43, n.6, jun, 2013. 
CVP values in this study was probably related to vasodilatation and the greater compliance of vascular beds caused by propofol, as demonstrated by the reduction in SVRI seen in this study. The mechanisms involved in the vasodilatation caused by propofol are controversial and it may be due to different factors, among them, the release of nitric oxide, which may be more related to the lipid emulsion used in the propofol formulation $\left(\right.$ Intralipid $\left.^{\circledR}\right)$ (DOURSOUT et al., 2002).

The RVSWI was significantly lower from the beginning to the end of the infusion in both groups, while the pulmonary vascular resistance index (PVRI) did not have a significant alteration over time (Table 1). The highest PVRI values observed in the MICRO treatment are explained by the constant higher values of mPAP observed in this group.

Whilst the mean pulmonary arterial pressure has remained with higher values in animals receiving MICRO, a more significant reduction of this parameter was observed in this group in relation to baseline values $-32.7 \%$ in comparison with $22.1 \%$ using EMU. No significant alterations were observed for the pulmonary artery occlusion pressure.

Respiratory depression is one of the most important side effects reported following propofol administration, with both a respiratory center depression and a decrease in the response to the arterial carbon dioxide tension in dogs (MUIR \& GADAWSKI, 1998). The respiratory rate (fR) was significantly lower from T15 until the end of infusion compared to the baseline values in dogs receiving MICRO, and for a shorter period in EMU (from T0 to T30). Although this significant reduction in $\mathrm{fR}$ was observed in our study, no mean values dropped below 12 and 11 breaths per minute (MICRO and EMU, respectively).

The $\mathrm{PaCO}_{2}$ values were below the reference range at the baseline evaluation in both groups, probably due to an hyperventilation, a physiological change expected in situations of stress (MUIR, 2008), result of the handling and restraint required during the recovery period after instrumentation. The normal $\mathrm{pH}$ values, the decreased $\mathrm{PaCO}_{2}$, and the low bicarbonate suggests the occurrence of a compensatory respiratory alkalosis at T-10, as explained by MADIAS (2008). Perhaps these alterations could have been attenuated if a longer recovery period was given after the instrumentation.

After the induction of anesthesia, the $\mathrm{pH}$ values decreased rapidly, reaching values compatible with a mild acidemia in both groups, corroborating with the findings of LOPES et al. (2007). It is suggested that the sudden alteration of the $\mathrm{CO}_{2}$ concentration after starting the infusion - low $\mathrm{PaCO}_{2}$ values to normal ones - caused a slight increase in the bicarbonate and $\mathrm{H}^{+}$concentration due to the dissociation of $\mathrm{H}_{2} \mathrm{CO}_{3}$, leading to acidemia.

The $\mathrm{PaO}_{2}$ only reached values close to $250 \mathrm{mmHg}$, even with the use of $100 \%$ oxygen. Whilst there is no data that can prove our hypothesis, it is believed that these findings may be due to the formation of atelectasis already during the instrumentation period. High oxygen concentrations have been associated with an increase in atelectasis formation that persists during the postoperative period (MAGNUSSON \& SPAHN, 2003).

In the recovery period, the animals presented a similar behavior with both formulations. The time for EXT, STR, AMB and TREC were $16.5 \pm 7.6,42,5 \pm 23.8,54.0 \pm 19.0$ and $60.5 \pm 21.0$ for the lipid emulsion and $6.5 \pm 3.9,38.8 \pm 8.4,54.7 \pm 25.3$ and $56.3 \pm 23.0$ for the microemulsion, showing no significant difference between treatments. The extubation time obtained with MICRO was similar to that observed by BEIER et al. (2009) after a targetcontrolled propofol administration of 120 minutes.

TSAI et al. (2007) demonstrated that $89.7 \%$ of the dogs anesthetized with a continuous infusion of propofol showed an excellent recovery without any signs of excitement or vocalization. However, opisthotonus was observed in two animals in the EMU group after the infusion ceased, lasting approximately 10 minutes. One of the animals receiving MICRO had a short lasting hyperextension of the right thoracic limb and on the left forelimb during the infusion, followed by the occurrence of opisthotonus, which disappeared when the infusion was discontinued at T90. One animal treated with MICRO had opisthotonus in the recovery period, which began 17 minutes after the infusion was stopped.

Transient signs of neurologic excitement during or after propofol administration have been reported, including opisthotonus (TSAI et al., 2007). According to BEVAN (1993), propofol seems to have an antagonistic effect on spinal aminoacid glycine and strychnine receptors, which could explain the opisthotonus and the myoclonus.

\section{CONCLUSION}

The new microemulsion used in our study presented some similarities when compared to the conventional propofol in lipid emulsion. Both formulations presented similar respiratory and

Ciência Rural, v.43, n.6, jun, 2013. 
recovery characteristics, but some differences were observed in hemodynamic parameters, highlighted by a marked reduction in CI and SVI with the use of the microemulsion of propofol.

Based only in the cardiorespiratory and clinical results, no advantages are seen in the use of microemulsion in dogs. Pharmacokinetic studies are being performed to search for possible advantages in its use.

\section{BIOETHICS AND \\ BIOSSECURITY COMMITTEE}

(Protocol 1.03/09).

\section{SOURCES AND MANUFACTURERS}

a - Isoforine ${ }^{\circledR}$, Cristália Produtos Químicos e Farmacêuticos, Itapira, SP.

b - BD Angiocath ${ }^{\mathrm{TM}}$, BD, São Paulo, SP.

c-Multiparameteric monitor 90496, Spacelabs Medical, Issaquah, Washington, USA.

d - Intro-Flex, Edwards Critical Care Division, Irvine, CA, USA. e - Swan-Ganz Catheter Model 132F5, Edwards Critical Care Division, Irvine, CA, USA.

f - Propovet $\left(10 \mathrm{mg} \mathrm{mL}^{-1}\right)$, pilot batch 001/2009, Ouro Fino Saúde Animal, Cravinhos, SP

g - Propovan $\left(10 \mathrm{mg} \mathrm{mL}^{-1}\right)$, Cristália Produtos Químicos e Farmacêuticos, Itapira, SP.

$\mathrm{h}$ - LIGNEA SEP-S10 Plus, Biosensor, Americana, SP.

\section{REFERENCES}

BEIER, S.L. et al. Effect of remifentanil on requirements for propofol administered by use of a target-controlled infusion system for maintaining anesthesia in dogs. American Journal of Veterinary Research, v.70, n.6, p.703-709, Jun. 2009. Available from: <http:// avmajournals.avma.org/doi/pdf/10.2460/ajvr.70.6.703>. Accessed: Nov. 26, 2012. doi: 10.2460/ajvr.70.6.703.

BEVAN, J.C. Propofol-related convulsions. Canadian Journal of Anaesthesia, v.40, n.9, p.805-809, Sept. 1993. Available from: $<$ http://link.springer.com/content/pdf/10.1007\%2FBF03009247>. Accessed: Nov. 27, 2012

BRANSON, K.R. Injectable and alternative anesthetics techniques In: TRANQUILLI, W.J.T.; GRIMM, K.A. (Ed.). Lumb \& Jones' veterinary anesthesia and analgesia. 4.ed. Oxford, UK: Blackwell Publishing, 2007. p.273-300.

DOURSOUT, M.F. et al. Role of propofol and its solvent, intralipid, in nitric oxide-induced peripheral vasodilatation in dogs. British Journal of Anaesthesia, v.89, n.3, p.492-498, Sept. 2002. Available from: <http://bja.oxfordjournals.org/content/89/3/492. long>. Accessed: Nov. 27, 2012. doi: 10.1093/bja/89.3.492.

DUBEY, P.K.; KUMAR, A. Pain on injection of lipid-free propofol and propofol emulsion containing medium-chain triglyceride: a comparative study. Anesthesia \& Analgesia, v.101, n.4, p.1060-1062, Oct. 2005. Available from: $<$ http://www.anesthesiaanalgesia.org/content/101/4/1060.long $>$. Accessed: Nov. 28, 2012. doi: 10.1213/01.ane.0000166951.72702.05.
FECHNER, J. et al. Comparative pharmacokinetics and pharmacodynamics of the new propofol prodrug GPI 15715 and propofol emulsion. Anesthesiology, v.101, n.3, p.626-639, Sept. 2004. Available from: <http://www.ncbi.nlm.nih.gov/ pubmed/15329587>. Accessed: Nov. 26, 2012.

FERRO, P.C. et al. Variáveis fisiológicas em cães submetidos à infusão contínua de diferentes doses de propofol. Ciência Rural, v.35, n.5, p.1103-1108, May 2005. Available from: $<$ http://www. scielo.br/pdf/cr/v35n5/a18v35n5.pdf>. Accessed: Nov. 27, 2012. doi: 10.1590/S0103-84782005000500018.

HETTRICK, D.A. et al. Alterations in canine left ventriculararterial coupling and mechanical efficiency produced by propofol. Anesthesiology, v.86, n.5, p.1088-1093, May 1997. Available from: <http://journals.lww.com/anesthesiology/ Fulltext/1997/05000/Alterations in Canine Left Ventricular arterial.12.aspx>. Accessed: Nov. 27, 2012.

JÚNIOR, A.S.C. et al. Microemulsões como veículo de drogas para administração ocular tópica. Arquivo Brasileiro de Oftalmologia, v.66, p.385-391, May/June, 2003. Available from: < http://www.scielo.br/pdf/abo/v66n3/v66n03a24.pdf $>$. Accessed: Nov. 26, 2012. doi: 10.1590/S0004-27492003000300025.

LOPES, P.C.F. et al. Efeitos de diferentes frações inspiradas de oxigênio sobre a dinâmica respiratória em cães submetidos à infusão contínua de propofol e mantidos em ventilação espontânea. Brazilian Journal of Veterinary Resarch and Animal Science, v.44, p.30-37, 2007. Available from: <http://www.revistas.usp.br/ bjvras/article/view/26587>. Accessed: Nov. 29, 2012.

MADIAS, N.E.A. Respiratory alkalosis and acidosis. In: ALPERN, R.J.H. (Ed.). Seldin and Giebisch's the kidney: physiology and pathophysiology. 4.ed. St. Louis: Elsevier, 2008. V.1, p.1721-1745.

MAGNUSSON, L.; SPAHN, D.R. New concepts of atelectasis during general anaesthesia. British Journal of Anaestheia, v.91, n.1, p.61-72, Jul. 2003. Available from: $<$ http://bja.oxfordjournals. org/content/91/1/61.long>. Accessed: Nov. 28, 2012. doi: 10.1093/ bja/aeg085.

MOREY, T.E. et al. Anesthetic properties of a propofol microemulsion in dogs. Anesthesia \& Analgesia, v.103, n.4, p.882-887, Oct. 2006. Available from: <http://www.anesthesiaanalgesia.org/content/103/4/882.long>. Accessed: Nov. 28, 2012. doi: 10.1213/01.ane.0000237126.57445.80.

MUIR, W.W., III; GADAWSKI, J.E. Respiratory depression and apnea induced by propofol in dogs. American Journal of Veterinary Research, v.59, n.2, p.157-161, Feb. 1998. Available from: <http://www.ncbi.nlm.nih.gov/pubmed/9492929>. Accessed: Nov. 27, 2012

MUIR, W.W., III. Pain and stress. In: GAYNOR, J.S.M. (Ed.). Handbook of veterinary pain management. New York: Elsevier, 2008. V.1, chapt.3, p.42-46.

NAKAIGAWA, Y. et al. Effects of graded infusion rates of propofol on cardiovascular haemodynamics, coronary circulation and myocardial metabolism in dogs. British Journal of Anaesthesia, v.75, n.5, p.616-21, Nov. 1995. Available from: $<$ http://bja.oxfordjournals.org/content/75/5/616.long $>$. Accessed: Nov. 26, 2012. 
OLESKOVICZ, N.C. et al. Efeitos clínicos da administração de duas formulações de medicação pré-anestésica em cadelas submetidas à ovariosalpingohisterectomia sob infusão contínua de propofol em microemulsão. In: SEMINÁRIO DE INICIAÇÃO CIENTÍFICA DA UDESC, 19., 2009 Lages, SC. Anais... Florianópolis: UDESC, 2009. p.116.
TSAI, Y.C. et al. Clinical comparison of recovery from total intravenous anesthesia with propofol and inhalation anesthesia with isoflurane in dogs. Journal of Veterinary Medical Science, v.69, n.11, p.1179-1182, Nov. 2007. Available from: <https:// www.jstage.jst.go.jp/article/jvms/69/11/69_11_1179/_article $>$. Accessed: Nov. 28, 2012. doi: 10.1292/jvms. $\overline{6} 9.1 \overline{1} 79$.

Ciência Rural, v.43, n.6, jun, 2013. 